\title{
Trust and Commitment in Maintaining Marriage among Teachers in Commuting Marriage in Kota Kinabalu Sabah
}

Joki Perdani Sawai, Mahirah Masdin, Rezki Perdani Sawai, Balan Rathakrishnan, Syaidatun Nazirah Abu Zahrin

To Link this Article: http://dx.doi.org/10.6007/IJARBSS/v10-i12/8162

DOI:10.6007/IJARBSS/v10-i12/8162

Received: 02 November 2020, Revised: 29 November 2020, Accepted: 16 December 2020

Published Online: 24 December 2020

In-Text Citation: (Sawai et al., 2020)

To Cite this Article: Sawai, J. P., Masdin, M., Sawai, R. P., Rathakrishnan, B., \& Zahrin, S. N. A. (2020). Trust and Commitment in Maintaining Marriage among Teachers in Commuting Marriage in Kota Kinabalu Sabah. International Journal of Academic Research in Business and Social Sciences, 10(12), 745-754.

\section{Copyright: @ 2020 The Author(s)}

Published by Human Resource Management Academic Research Society (www.hrmars.com)

This article is published under the Creative Commons Attribution (CC BY 4.0) license. Anyone may reproduce, distribute, translate and create derivative works of this article (for both commercial and non-commercial purposes), subject to full attribution to the original publication and authors. The full terms of this license may be seen at: http://creativecommons.org/licences/by/4.0/legalcode

\section{Vol. 10, No. 12, 2020, Pg. 745 - 754}

Full Terms \& Conditions of access and use can be found at http://hrmars.com/index.php/pages/detail/publication-ethics 


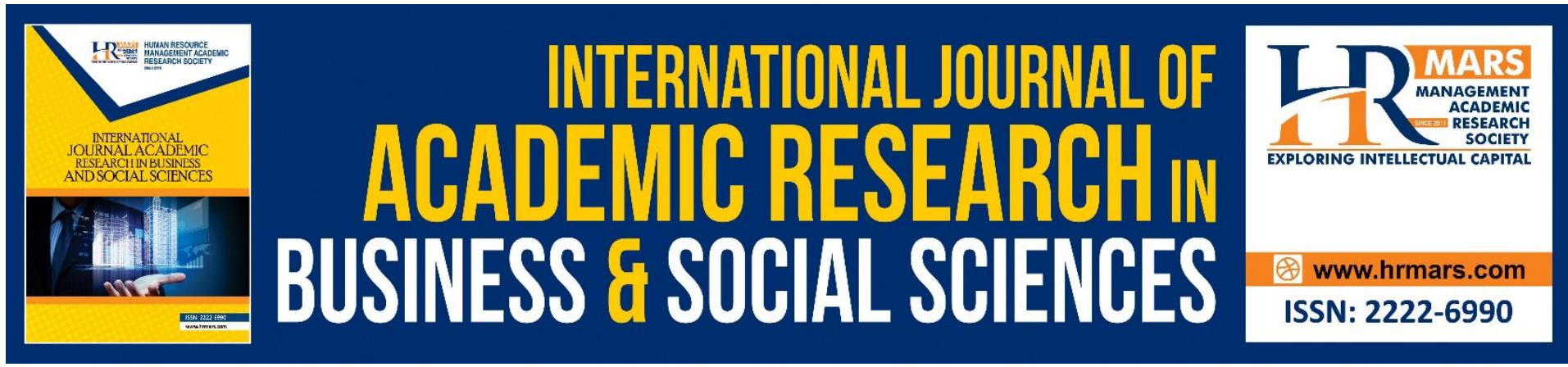

\title{
Trust and Commitment in Maintaining Marriage among Teachers in Commuting Marriage in Kota Kinabalu Sabah
}

\author{
Joki Perdani Sawai ${ }^{1}$, Mahirah Masdin ${ }^{1}$, Rezki Perdani Sawai ${ }^{2,}$ \\ Balan Rathakrishnan ${ }^{1}$, Syaidatun Nazirah Abu Zahrin ${ }^{3}$ \\ Faculty of Psychology \& Education, Universiti Malaysia Sabah ${ }^{1}$, Faculty of Leadership \& \\ Management, Universiti Sains Islam Malaysia², School of Liberal Studies \& Institute of Islam \\ Hadhari, Universiti Kebangsaan Malaysia ${ }^{3}$
}

\begin{abstract}
Long-distance marriages are commonly performed by dual-career couples particularly teachers. This study aimed to measure the relationship between trust and commitment with maintenance of marriage among teachers who living in commuter marriages. This study was conducted on 110 teachers around Kota Kinabalu Sabah from secondary and primary schools. The research design was a quantitative study using a set of questionnaires to get feedback from respondents. The Dyadic Trust Scale (DTS) (Larzelere \& Huston, 1981), The Investment Model Scale (IMS) (Rusbult, Martz \& Agnew, 1998), Relationship Maintenance Scale (RMS) (Chonody, Killian, Gabb \& Dunk-West, 2017) were used to measure the variables involved. The results showed that trust and commitment are positively related to marriage maintenance. The implications of this study are for teachers to acknowledge that trust and commitment play an important role in their marriage.
\end{abstract}

Keyword: Communal Marriage, Love, Teachers, Job Mobility

\section{Introduction}

Commuting marriage (CM) also known as long distance relationships have become increasingly common since the beginning of the Information Age in the United States (Ladd, 2007; Canary \& Dainton, 2003). It is becoming increasingly popular among couples pursuing dual careers. It also commonly occurs for some teachers who have a spouse who lives far away. Commuter marriages usually occur when two couples have their own jobs but in different places or away from each other. Due to job mobility, the couple's occupational pursuits have created a need for many romantically involved couples to be geographically separated (Arditti \& Kaufmann, 2004). According to Gerstel and Gross (1982), commuting lifestyle among marriage couples are where couples maintain separate residences in two geographic areas at least three nights a week. Usually, the couples will meet at a specific times such as weekend or holiday and be apart again separate again after spending a few days together. 
Commuting marriage (CM) has been defined in several ways. As Canary and Dainton (2003) defined CM depends on how partners perceive their relationship to be long-distance or not. The consideration based on whether or not they can see each other as much as they like because of distance. Some partner view their marriage as a long-distance because they cannot see each other every day, or that means they do not live in the same house but in the same area. However, some partner consider their marriage as a long-distance because they living far away due to distance. Stafford (2005) simply defined commuting marriage as they live in a city or town different from their partners.

In long-distance marriages, the challenge faced by the couple is to maintain the relationship. This is because factors that remain separate from each other tend to challenge the level of trust in each other. An individual cannot physically see his or her partner but only communicates via telephone conversation. According to Dainton and Aylor (2001), physical distance somehow facilitates relational stability for those who occasionally see each other face-to-face, but physical distance combined with lack of face-to-face interaction may have a negative effect on relationship.

Trust is considered an important aspect of marriage, especially for those who live far from each other (Simpson, 2007). Without trust, the relationship will not functioning well and is hesitant to invest in the relationship. According to Dewi and Sudhana (2013), living apart between spouses leads to easily misunderstanding and distrust of each other. This is because distance creates constraints in communication. Meanwhile, Helgeson (1994) stated that most long-distance marriage couples believe their relationship will not last long. This is because, the difficulty of meeting each other makes it easier for the couple to grow up emotionally and tend to doubt their partner (Le \& Agnew, 2001).

Trust is a dynamic process. Although spouses have built their trust and are confident that their level of trust will not change, their trust may decline only because of distance (Asif \& St. Saim, 2018). This issue remains a concern in the studies of marital relationships for couples who living apart (Asif \& St. Saim, 2018). Meanwhile, Wieselquist, Rusbult, Foster and Agnew (1999) proposed that the change in trust related to commitment between couples. Individuals come to trust their partner when they are committed to them even though they live far from each other. Individual commitments are often sought from their spouse such as living expenses or telephone communication. Also, their roles and responsibilities are much more burdensome because they do not face and bear them together. This kind of commitment plays an important role in the maintenance of marriage. When commitment changes, individuals are more likely to question their spouse, which may lead to mistrust and damage the relationship.

So, that is why the other challenge that couples face when living separately is their commitment to each other. Commitment in marriage couples usually referred to house chores, living expenses or meeting their needs (Rhoades, Stanley \& Markman, 2009). But, different with marriage couple who living separately because of dual-income or career. Their form of commitment inherent in the marriage relationship is difficult to fill. This is because, some commitment can be fulfilled only if the couple resides together within the specified period before returning to the long-distance relationship (Nur Kholisoh, 2018). How are couples committed to their marriages to maintain marital relationships when they are 
geographically separated? Therefore, this study was conducted to investigate relationship maintenance through trust and commitment among teachers living as commuter marriages.

\section{Objectives of the Study}

The objectives of the study are

1. To investigate the relationship between trust and marriage maintenances among teachers in commuting marriage.

2. To investigate the relationship between commitment and marriage maintenances among teachers in commuting marriage.

\section{Methodology}

a. Study Design

Quantitative method using survey-questionnaire was used in this study. The study design was selected because it is appropriate to look at the relationship between variables (Fischer, Boone \& Neumann, 2014). In this study, we investigate the relationship between trust and commitment with marriage maintenance.

\section{b. Respondent and Location of the Study}

The respondents of this study involved teachers in commuting marriage. A total of 110 teachers were recruited using purposive sampling techniques. The sampling technique was used as it is appropriate to obtain a sample of studies that have the characteristics specified in a study (Cresswell \& Plano Clark, 2011). As in this study, the priority feature has been set was the teacher who is in a commuting marriage with partner. The study areas were primary and secondary schools around Kota Kinabalu Sabah.

\section{c. Instruments}

Three sets of questionnaires were used to measure each of the variables represented. Trust variable was measured using The Dyadic Trust Scale (DTS) (Larzelere \& Huston, 1981). DTS is a short-form questionnaire consisting 8 items measuring trust with a one-factor model.

Meanwhile, commitment was measured using The Investment Model Scale (IMS) (Rusbult, Martz \& Agnew, 1998). An instrument consisting of 15 items was used to assess the degree to which individuals are committed to value their relationships.

The dependent variable of relationship maintenance was assessed using Relationship Maintenance Scale (RMS) (Chonody, Killian, Gabb \& Dunk-West, 2017). RMS consists of eight single factors to investigate the degree of effort individuals spend to maintain their relationships.

\section{d. Procedure}

The researcher obtained permission from the Ministry of Education in Malaysia and the Sabah Education Department to conduct a study on school teachers. The duration of consent granted to conduct the study on the target respondents was 6 months (April 1 to September 2, 2019). 
After receiving a permission letters from Ministry of Education Malaysia and the Sabah Education Department, the researcher conducted a simple rapport with the Headmaster of each school visited to identify the teachers who were living in a commuting marriage. Based on the information received, the researcher left a set of questionnaires. The time given to respondents to complete a set of questionnaires was one week.

\section{e. Data Analysis}

The data were analyzed descriptively to identify the background of respondents. The hypotheses of the study was tested using correlation method. The IBM SPSS program was used to analyze the study data.

\section{Result and Discussion}

a. Respondents Background Information

Table 1

Background Information among Teachers in Commuting Marriage in Kota Kinabalu Sabah

\begin{tabular}{|c|c|c|}
\hline Percentages (\%) & Frequencies (N) & \\
\hline & & Gender \\
\hline 40 & 44 & Male \\
\hline \multirow[t]{2}{*}{60} & 66 & Female \\
\hline & & $\begin{array}{l}\text { First Marriage } \\
\text { Respondent }\end{array}$ \\
\hline 85.5 & 94 & Yes \\
\hline \multirow[t]{2}{*}{14.5} & 16 & No \\
\hline & & Partner \\
\hline 72.7 & 80 & Yes \\
\hline \multirow[t]{2}{*}{27.3} & 30 & No \\
\hline & & Duration of Commuting Marriage \\
\hline 22.7 & 25 & Below 1 year \\
\hline 22.7 & 25 & 1 years \\
\hline 20.9 & 23 & 2 years \\
\hline 20.9 & 23 & 3 years \\
\hline 5.5 & 6 & 4 years \\
\hline 4.5 & 5 & 5 years \\
\hline \multirow[t]{2}{*}{2.7} & 3 & 6 years \\
\hline & & Intention to Divorce \\
\hline 16.4 & 18 & Yes \\
\hline \multirow[t]{2}{*}{83.6} & 92 & No \\
\hline & & Academic Level of Respondents \\
\hline 17.3 & 19 & Diploma \\
\hline 82.7 & 91 & Degree \\
\hline
\end{tabular}




$\begin{array}{rrr}10.9 & 12 & \text { SPM } \\ 12.7 & 14 & \text { STPM } \\ 29.1 & 32 & \text { Certificates } \\ 31.8 & 35 & \text { Diploma } \\ 15.5 & 17 & \text { Degree } \\ & & \\ & & \text { Respondents' Work Position } \\ 100 & 110 & \text { Grade } 41 \text { and above } \\ & & \\ & & \text { Partners' Work Position } \\ 7.3 & 8 & \text { Grade 41 and above } \\ 3.6 & 4 & \text { Support I (Grade 27-38) } \\ 0.9 & 1 & \text { Support II (Grade 17-26) } \\ 9.1 & 10 & \text { Support III (Grade 1-16) } \\ 25.5 & 28 & \text { Private Sector } \\ 29.1 & 32 & \text { Part-Time } \\ 15.5 & 17 & \text { Not Working } \\ 9.1 & 10 & \text { Self-Employed } \\ & & \\ 20.9 & & \text { Family's Economic Manager } \\ 40 & 23 & \text { Husband } \\ 39.1 & 44 & \text { Wife } \\ & 43 & \end{array}$

The total of 110 teachers involved in the study consisted of 44 male (40\%) and 66 female $(60 \%)$. Most of the 94 persons (85.5\%) claimed that the current marriage was the first marriage and only 16 persons (14.5) reported as a second marriage. So did their spouse, of whom 80 persons (72.7\%) claimed was the first marriage and 30 persons (27.3) as a second marriage.

For duration living in a commuter marriage, 25 persons (22.7\%) reported that living in commuter marriage for 1 years, 23 persons (20.9\%) for 2 years and 3 years respectively. The longest duration is 6 years where 3 persons reported to be living separately with their partner. There are no inclusion criteria for choosing duration. The focus of the study was on respondents who living in a commuter marriage without stressing on the duration. Interestingly, even though they lived separately with their partners, only 18 persons (16.4) said they had a desire to end a marriage meanwhile 92 persons $(83.6 \%)$ reported having no intention of divorce.

A total 91 respondents $(82.7 \%)$ reported that the highest level of education was a Degree and only 19 persons (17.3\%) had a Diploma. For partners, 35 persons (31.8\%) were Diploma, 32 persons (29.1\%) Certificates, 17 persons (15.5\%) Degree, 14 persons $(12.7 \%)$ STPM level and 12 persons (10.9\%) SPM level. For the job position, all respondents reported as Grade 41 and above. Meanwhile for partner, 32 persons (29.1\%) reported their 
employment status as a part-timer, 28 persons (25.5\%), worked in the private sector, 17 persons (15.5\%) did not work, 10 persons (9.1\%) respectively self-employed and Support III (Grade 1-16), 8 persons (7.3\%) Grade 41 and above, 4 persons (3.6\%) as a Support I (Grade 27-38) and one person (0.9\%) as a Support II (Grade 17-26).

For family financial managers, 44 persons (40\%) reported that family finances were managed by the wife and and 23 persons (20.9) said the husband was responsible for the management. Meanwhile, 43 persons $(39.1 \%)$ said they manage their own money or income without the intervention of a partner.

\section{b. Hypotheses Testing}

Table 2

Results of Hypotheses Testing

\begin{tabular}{crrrr}
\hline & \multicolumn{3}{c}{ Commitment } & \multicolumn{2}{c}{ Trust } \\
\hline Sig. & $\mathrm{R}$ & Sig. & $\mathrm{r}$ & \\
\hline .009 & $.247^{* *}$ & .009 & $.249^{* *}$ & Marriage Maintenance
\end{tabular}

$r<.001^{* *}$

Based on the result shown in Table 2, hypothesis testing revealed that trust in marriages correlated with marital maintenance $(r=.249 * *, p<.001)$ among teachers in commuting marriage. The relationships shown is a low positive correlation, where high levels of trust increase marital maintenance among teachers living in a commuter marriage. This finding suggest that even when couples are living separately, they still have a high degree of trust in their partner. This is because, they believe that by trusting their partner, they will be more living comfortably as a distant marriage. These couples do not view long distance marriages as a cause for suspicion with each other. Instead, long-distance relationships will strengthen the bond of marriage.

According to Peterson (2014), distance makes the heart grow fonder. This result supported by previous study such as Pistole, Roberts and Mosko (2010) also found that the distance relationship between married couples is related to higher intimacy. In contrast to couples who often meet face to face and spend time together, they tend to be bored and invest less in relationships (Peterson, 2014; Dainton et al., 2020). Meanwhile, Heller (2000) stated that trust is believing that that the person who is trusted will do what is expected.

Moreover, the role of trust in improving marital maintenance can be explained by a sense of independence and autonomy. Living separately helps them develop a sense of independence and more autonomy (Mietzner \& Lin, 2005). Couples feel more free to be independent and self-deprecating when they place their confidence in their partner. Especially in today's context, most married couples are more autonomous, with the wife managing her own finances and the husband managing his own needs. 
The result also indicate that the commitment they place to the relationship can improve marital maintenance $\left(r=.247^{* *}, p<.001\right)$. The direction shown is positive, which is that positive or high commitment in the marriage relationship can enhance marital maintenance among commuter marriages. The role of commitment in enhancing marital maintenance can be explained by the appreciation of the time spent while meeting their partner (Jacobs \& Lyubomirsky, 2013). These couples are committed to each other because of their lack of time, so they invest in relationships to make them successful. In line with the descriptive results found that $83.6 \%$ of respondents reported that they had no intention of divorcing their spouse.

\section{Conclusion}

Every married person wants to live with their partner without having to be apart or live apart. Living separately between a married couple can lead to divorce. Therefore, trust and commitment in marriage are essential for the maintenance of marriage. This study was conducted to examine the relationship between trust and commitment with marital stability among teachers living in commuter marriages. The results show that trust and commitment are positively related to the maintenance of marriage. Both of these aspects have been shown to be important aspects for long-distance marriage. The implication of this study is that both spouses need to trust each other and give a higher commitment in their marriage for the marital relationship to last. The commitment they place to the relationship can improve marital maintenance as well, despite of being apart from each other due to their job requirements.

Conclusion should be consisted of major findings of this study. Researchers need to conclude major findings first and then make appropriate suggestions. Suggestions should be relevant to the problem with the explanation that how this recommendation is appropriate in this particular context and what will be the benefits of this recommendation if implemented as per your findings. Overall study is acceptable with minor correction mentioned above. However, authors need to put some lines/sentences in order to revise the conclusion and recommendations part

\section{Acknowledgement}

Special thanks to Universiti Kebangsaan Malaysia for the grant DPP-PCU-2020 and Skim Geran Penyelidikan UMS (SGPUMS) project code SBK0436-2018 Love, Trust, Commitment and Relationship Maintenance among Commuter Marriage.

\section{References}

Arditti, J., \& Kauffman, M. (2004). Staying close when apart: intimacy and meaningin longdistance dating relationships. Journal of Couple and Relationship Therapy, 3(1), 2752.

Asif, A., \& St Saim. (2018). Trust and Marital Satisfaction among Single and Dual Career Couples. Dubai: MedCrave Group LLC.

Canary, D. J., \& Dainton, M. (Eds.). (2003). Maintaining relationships through communication: Relational, contextual, and cultural variations. Mahwah, NJ, US: Lawrence Erlbaum Associates Publishers. 
Chonody, J. M. Killian, M., Gabb, J., \& Dunk-West, P. (2017). Understanding Everyday Relationship Work: The Development of a Relationship Maintenance Scale. Advances in Social Work, 17(2), 355-368.

Creswell, J. W., \& Plano Clark, V. L. (2011). Designing and Conducting Mixed Methods Research ( $2^{\text {nd }}$ Ed.), Sage Publications, Los Angeles.

Darwish, S., Alzayed, S., \& Ahmed, U. (2020). How Women in Science can Boost Women's Entrepreneurship: Review and Highlights. International Journal of Innovation Creativity and Change, 14(1), 453-470.

Dainton, M., \& Aylor, B. (2001). A relational uncertainty analysis of jealousy, trust, and maintenance in long-distance versus geographically close relationships. Communication Quarterly, 49, 172-188.

Dewi, N. K., \& Sudhana, H. (2013). Hubunganantara komunikasi interpersonal pasutri dengan keharmonisan dalam pernikahan (The relationship between interpersonal communication couples with marital harmony). Jurnal Psikologi Udayana, I(1),2231.

Fischer, H. E., Boone, W. J., \& Neumann, K. (2014). Quantitative Research Designs and Approaches. Ohio: Miami University.

Gerstel, N., \& Gross, H. E. (1982). Commuter marriages: A review. Marriage \& Family Review, 5(2), 71-93.

Helgeson, V. S. (1994). Relation of agency and communion to well-being: Evidence and potential explanations. Psychological Bulletin, 116(3), 412-428.

Jacobs, K. B., \& Lyubomirsky, S. (2013). The Journal of Positive Psychology: Dedicated to furthering research and promoting good practice. The Journal of Positive Psychology, 8(3), 196-206.

Ladd, P. D. (2007). Relationships and patterns of conflict resolution: a reference book for couples counseling. Lanham, MD: University Press of America.

Le, B., \& Agnew, C. R. (2003). Commitment and its theorized determinants: A meta-analysis of the investment Model. Personal Relationships, 10, 37-57.

Larzelere, R. E., \& Huston, T. L. (1980). The Dyadic Trust Scale: Toward understanding interpersonal trust in close relationships. Journal of Marriage and the Family, 42(3), 595-604.

Mietzner, S., \& Lin, L.-W. (2005). Would You Do It Again? Relationship Skills Gained In a LongDistance Relationship. College Student Journal, 39, 192-200.

Nur Kholisah, D. A. (2018). Why do They "Commuter Marriage"? Interpersonal Communication: the Commuter Marriage Couple Cases. International Conference on Media and Communication Studies (ICOMACS 2018).

Peterson, K. K. (2014). Distance Makes the Heart Grow Fonder: Do Long-Distance Relationships Have an Effect on Levels of Intimacy in Romantic Relationships? Global Tides, 8(8).

Pistole, C. M., Roberts, A., \& Mosko, J. E. (2010). Commitment Predictors: Long-Distance Versus Geographically Close Relationships. Journal of Counseling \& Development, 88, 146-153.

Rhoades, G. K., Stanley, S. M., \& Markman, H. J. (2009). The pre-engagement cohabitation effect: A replication and extension of previous findings. Journal of Family Psychology, 23, 107-111. 
Rusbult, C. E., Martz, J. M., \& Agnew, C. R. (1998). The Investment Model Scale: Measuring commitment level, satisfaction level, quality of alternatives, and investment size. Personal Relationships, 5(4), 357-391.

Stafford, L. (2005). Maintaining long-distance and cross-residential relationships. Mahwah, NJ. Lawrence Erlbaum Associates.

Wieselquist, J., Rusbult, C. E., Foster, C. A., \& Agnew, C. R. (1999). Commitment, prorelationship behavior, and trust in close relationships. Journal of Personality and Social Psychology, 77(5), 942-966. 